\title{
FORMALISASI SYARI'AT ISLAM DI INDONESIA: PENDEKATAN PLURALISME POLITIK DALAM KEBIJAKAN PUBLIK
}

\author{
M. Zainal Anwar \\ Institute for Research and Empowerment Yogyakarta \\ Email: zainalanwar@gmail.com
}

\section{Abstract}

This paper discuss about the formalization of Islamic shari'a in public policy area in Indonesia. The writer will use a pluralism of political perspective to discuss this paper. In pluralism of political approach in public policy, there several questions will guide a writer in this study. The important questions in pluralism of political approach are; who engaged in the process of decision-making; who's choice that accepted as a decision; and who can put up influence to the outcomes. After we discuss wide range a concept of pluralism of politics and public policy, this paper will study a discourse and the aspiration of Islamic sharia; formalization from district level until central level and the minorities' response toward public policy that oriented to special religion. This paper, systematically, will begin from the perspective of pluralism of politics to examine many problems that discussed and will be finished with the conclusion.

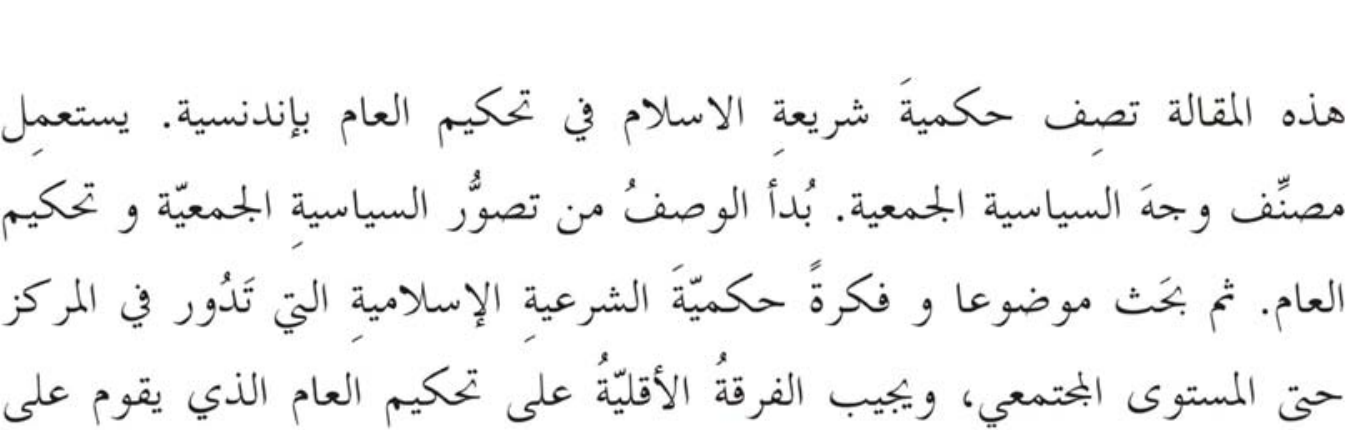

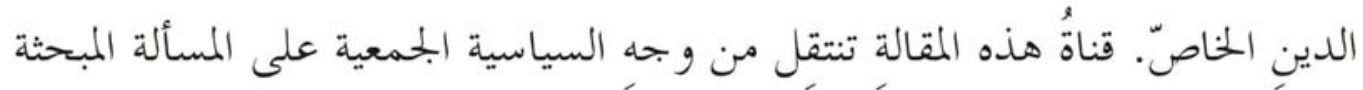
وتُتُتَهى بالإختتام.

Keywords: Formalisasi Syariah, Politik, Islam, Pluralisme. 


\section{A. Pendahuluan}

Di bumi Indonesia, isu penerapan Syariat Islam bukanlah sesuatu yang baru. Usaha seperti ini memiliki akar historis panjang. Anthony Reid menunjukkan bahwa sejak awal abad ke- 17 M., hukum Islam yang ketat telah diterapkan secara parsial di Banten (Jawa Barat) dan Aceh, misalnya hukum potong tangan diberlakukan kepada para pencuri. ${ }^{1}$ Hal ini menunjukkan betapa sejak awal sejarah Islam di Nusantara, isu Syariat Islam telah bergema dan telah menjadi perhatian umat Islam saat itu.

Di masa penjajahan Belanda, tepatnya pada 25 Mei 1670, pemerintah Belanda melalui VOC (Verenigde Oost Indische Compagnie) mengeluarkan legislasi pertama yang berisi kompilasi hukum perkawinan dan waris Islam yang diterapkan di pengadilan VOC di Indonesia. Legislasi Belanda -pasca bubarnya VOC- terkait dengan penerapan Syariat Islam adalah dekrit Kerajaan 1882 tentang pembentukan "Pengadilan Agama" di Jawa dan Madura (staatsblad 1882 no. 152), sekalipun dekrit tersebut mengakui bahwa sebagian besar pribumi Indonesia tunduk kepada hukukm adat yang dijalankan oleh pengadilan pribumi. Secara keseluruhan, kebijakan-kebijakan Belanda selama berkuasa di Indonesia telah menempatkan hukum Islam ke tempat yang inferior. ${ }^{2}$

Saat ini, upaya untuk menerapkan Syariat Islam di era Indonesia modern tampaknya selalu bergejolak. Bahkan, perjuangan untuk hal tersebut dalam suatu regulasi terkadang menimbulkan pro dan kontra, terutama ketika diarahkan pada upaya mendapatkan legitimasi dan operasionalisasi melalui negara secara formal. Pada masa perumusan konstitusi baru bagi negara Indonesia merdeka, para pemimpin Muslim anggota BPUPKI (Badan Pelaksana Usaha-usaha Persiapan Kemerdekaan Indonesia) telah berupaya memasukkan suatu frasa dalam mukadimah UUD 45 yang akan memberi legitimasi politis-hukum bagi warga muslim Indonesia dalam pelaksanaan Syariat Islam. Mukadimah ini belakangan disebut dengan Piagam Jakarta. Frasa yang diamaksud adalah dengan kewajiban melaksanakan Syariat Islam bagi pemeluk-pemeluknya. Tujuh kata inilah yang diyakini memberi landasan konstitusional penerapan Syariat Islam di Indonesia. ${ }^{3}$

1 Anthony Reid, Southeast Asia in The Age of Commerce 1450-1680. Vol. 1: The Lands Below the Winds, (New Haven: Yale University Press, 1988), hal 143.

2 Taufik Adnan Amal dan Samsu Rijal Panggabean, Politik Syariat Islam; Dari Indonesia hingga Nigeria, (Jakarta: Pustaka Alvabet, Desember 2004), hal 55-56.

3 Seperti terlihat dalam sejarah, upaya ini akhirnya tidak berhasil, terutama karena mendapat tentangan keras dari kelompok minoritas politisi non-muslim dan kelompok nasionalis-sekuler yang mayoritasnya adalah kaum muslim juga. Wahyuddin Halim, "Gerakan Formalisasi Syariat 
Ketika orde baru, perbincangan tentang Piagam Jakarta seolah menjadi sesuatu yang telah selesai. Pada masa itu, perdebatan tentang Syariat Islam bahkan dilarang sama sekali. Boleh jadi, hal in karena rejim Orde Baru saat itu menerapkan kebijakan asas tunggal bagi seluruh organisasi sosial politik dan kemasyarakatan melalui TAP MPR No/II/1978 tentang Pedoman Penghayatan dan Pengamalan Pancasila (P4). ${ }^{4}$

Bahkan, rezim Soeharto waktu itu tidak memberi ruang perdebatan sedikitpun untuk memperbincangkan Piagam Jakarta. Akan tetapi, beberapa produk undangundang berkenaan dengan kepentingan khusus umat Islam disahkan selama pemerintahan Orde baru. Ini misalnya terlihat pada UU perkawinan (1974), PP tentang Wakaf (1977), UU tentang Peradilan Agama (1989), UU tentang Sistem Perbankan Islam (1992), dan Inpres tentang Kompilasi Hukum Islam (KHI). ${ }^{5}$

Namun demikian, sikap akomodasi negara terhadap beberapa ketentuan Syariat Islam tersebut belum memuaskan bagi kelompok Islam militan. Maka, seiring dengan arus deras reformasi, banyak bermunculan gerakan Islam yang orientasinya adalah penegakkan syariat Islam. Secara kultural dan politik, mereka memperjuangkan Piagam Jakarta sebagai entry point pemberlakuan Syariat Islam secara menyeluruh; baik hukum perdata maupun hukum pidananya. Sebab dalam pandangan mereka, negara belum banyak menyalurkan aspirasi mereka secara luas terhadap orientasi penegakkan syariat Islam. Itu sebabnya, mereka secara intensif bersama partai-partai Islam memperjuangkan Piagam Jakarta. Ini terlihat jelas dalam dua momentum ST MPR Tahun 2000 dan $2001 .^{6}$

Hal ini terlihat jelas ketika penguasa Orde Baru, Soeharto, tumbang. Seiring pergeseran pendulum kekuasaan pasca orba, beragam wacana yang selama ini dianggap selesai, tiba-tiba menyeruak kembali dalam kehidupan berbangsa dan bernegara. Habibie, yang menggantikan Soeharto, dalam masa pemerintahannya yang singkat (1998-1999) mengeluarkan dua produk hukum yakni UU tentang penyelenggaraan Haji dan Pengelolaan Zakat (1999).Semua produk hukum yang

Islam melalui Instrumen Negara; Refleksi Kritis atas KPPSI," dalam Kamaruddin Amin, dkk., Quo Vadis Islamic Studies in Indonesia? (Current Trends and Future Challanges), (Makassar: PPs UIN Alauddin Makassar, 2006), hal 126. Lihat pula Taufik Adnan Amal dan Samsu Rijal Panggabean, Politik Syariat Islam, hal 60-61.

4 S. Yunanto, et al., Gerakan Militan Islam di Indonesia dan di Asia Tenggara, Jakarta: The Ridep Institute, Januari 2003), hal 44.

Wahyuddin Halim, "Gerakan Formalisasi,” hal 128.

6 Khamami Zada, "Wacana Syariat Islam; Menangkap Potret Gerakan Islam di Indonesia," dalam Jurnal Taswirul Afkear Edisi No. 12 Tahun 2002, hal 28. 
terlihat mengakomodasi beberapa elemen Syariat Islam ini diterapkan tanpa merujuk sama sekali ke Piagam Jakarta. ${ }^{7}$

Setelah jatuhnya Soeharto dan digulirkannya era desentralisasi dan otonomi daerah, gagasan tentang penerapan Syariat Islam kembali mengemuka. Upaya untuk menggali dan memunculkan kembali "tujuh kata” yang hilang dalam Piagam Jakarta tersebut mulai digulirkan beberapa kelompok.

Di era reformasi saat ini, di mana kebebasan berpendapat dan berorganisasi diberi tempat seluas-luasnya, aspirasi setiap kelompok mendapatkan ruang dan diakomodasi oleh negara atau pemerintah. Dalam era otonomi dan desentralisasi, setiap daerah memiliki otoritas dalam batas tertentu untuk mengurus wilayahnya sesuai kehendak masyarakat di daerah tersebut. "Peluang" inilah yang tampaknya memicu kelompokkelompok masyarakat di beberapa daerah untuk membuat kebijakan publik yang bernuansa Islami dalam bentuk peraturan daerah yang mengacu pada Syariat Islam.

Inilah tampaknya awal dari gegap gempita wacana Syariat Islam di Indonesia pasca orde baru. Setelah 9 tahun reformasi, perjuangan memformalisasikan syariat islam kian hari kian semarak. Sejak Otonomi daerah dilaksanakan hingga Juli 2006, tercatat 56 kebijakan peraturan daerah dalam berbagai bentuk; Peraturan Daerah (perda), qanun, surat edaran, dan keputusan kepala daerah. Produk kebijakan daerah tersebut secara tegas berorientasi pada ajaran moral Islam hingga pantas disebutkan perda Syariat Islam. ${ }^{8}$

Dalam konteks pluralisme dimana banyak kelompok yang seharusnya memiliki akses yang sama dalam mewarnai proses kebijakan, kelompok muslim, dengan adanya perda syariat tersebut, berusaha memperoleh hak istimewa dengan memunculkan kebijakan yang diinginkannya. Di aras lain, banyak kelompok yang belum sepakat dengan penerapan kebijakan publik yang bernuansa Syariat Islam. Kelompok ini biasanya adalah minoritas non-muslim dan kalangan muslim moderat. ${ }^{9}$

Bukti-bukti akomodasi itu, oleh Bahtiar Effendy, digolongkan ke dalam empat jenis: (1) akomodasi struktural; (2) akomodasi legislatif; (3) akomodasi infrastruktural; dan (4) akomodasi kultural. Lebih jauh lihat Bahtiar Effendy, Islam dan Negara; Transformasi pemikiran dan Praktik Politik Islam di Indonesia, Alih bahasa: Ihsan Ali Fauzi, (Jakarta: Paramadina, Oktober, 1998), hal 273-310.

8 Siti Musdah Mulia, "Peminggiran Perempuan dalam Perda Syariat," dalam Jurnal Tashwirul Afkar Edisi No. 20 Tahun 2006, hal 21.

9 Dalam hal ini, menarik untuk menyitir jawaban Marzuki Wahid, yang saat itu sedang meneliti tentang pola pemberlakuan Syariat Islam di beberapa daerah, ketika ditanya tentang respon kalangan non-muslim terhadap Syariat Islam. Marzuki menilai sejauh ini kalangan nonmuslim ketakutan untuk merespon. Wawancara dengan Marzuki Wahid, "Syariat Islam Butuh Reinterpretasi," dalam Halqoh, Edisi XVI/2002, hal 17. 
Dari pemaparan di atas, penulis memunculkan rumusan masalah sebagai berikut; pertama, bagaimana aspirasi kelompok, dalam hal ini keinginan menerapkan Syariat Islam bisa terakomodasi hingga menjadi kebijakan publik, khususnya perda syariat Islam. Kedua, bagaimana pola perjuangan formalisasi Syariat Islam dilakukan, dan Ketiga, bagaimana respon kelompok lain ${ }^{10}$ terhadap aspirasi tersebut?

Tulisan ini mengulas formalisasi Syariat Islam dalam aras kebijakan publik di Indonesia. Untuk mengulas hal tersebut, penulis menggunakan perspektif pluralisme politik. Dimulai dari pembahasan konsep pluralisme politik dan kebijakan publik, lalu membahas wacana dan aspirasi formalisasi Syari'at Islam yang bergaung di level Pusat hingga daerah, dan respon kaum minoritas terhadap kebijakan publik yang merujuk pada agama tertentu. Alur tulisan ini beranjak pada perspektif pluralisme politik terhadap persoalan yang diangkat dan diakhiri dengan penutup.

\section{B. Pluralisme Politik dan Kebijakan Publik: Kerangka Teori}

Dari sudut pandang pluralisme, politik merupakan proses interaksi warga negara untuk mempengaruhi arah kebijakan. Pandangan ini melahirkan dua masalah pokok yang menjadi perhatian kaum pluralis. Pertama, masalah non-partisipan yaitu warga negara yang tidak aktif yang disisihkan atau menyisihkan diri dari proses yang ada. Kedua, peran serta warga yang berlimpah. Tingkat peran serta yang sangat tinggi dari berbagai kelompok bisa menyebabkan pengambil kebijakan tidak mampu bergerak jika dan bilamana keputusan mereka tentang isu yang penting banyak melanggar berbagai kepentingan yang ada. ${ }^{11}$

Kata kunci dalam memahami pluralisme adalah keberbedaan (difference) dan keberagaman (diversity). Dalam negara modern yang liberal saat ini, tidak ada lagi satu kelompok, kelas atau organisasi yang mampu mendominasi masyarakat. Pluralisme melihat pemisahan antara negara dan civil society; antara kekuasaan politik dan ekonomi; dan beragam kepentingan dalam berbagai area kebijakan. Pluralisme meyakini bahwa kekuasaan tidak boleh bertumpuk pada satu kelompok dan harus menyebar. Karena itulah, peran negara adalah mengatur atau membuat

10 Maksud kelompok lain adalah kelompok non-muslim, kelompok nasionalis atau kelompok muslim yang tidak sepakat dengan formalisasi Syariat Islam.

11 David E. Apter, Pengantar Analisa Politik (Introduction to Political Analysis), terj. Tim Penerjemah Yasogama Yogyakarta, (Jakarta: PT. Rajawali, 1985), hal 450. 
regulasi terhadap pertentangan-pertentangan yang mungkin timbul diantara kelompok-kelompok dalam masyarakat agar tidak mendominasi kepentingankepentingan tertentu. ${ }^{12}$

Dalam analisanya, kaum pluralis memanfaatkan dan mengembangkan dua prinsip pokok pemikiran politik kaum institusionalis yaitu; kontrol legislatif terhadap eksekutif dan kedaulatan rakyat. Dengan kata lain, bagaimana kekuasaan negara dikendalikan oleh rakyat dan bagaimana rakyat diwakili sebagai warga negara. Berdasarkan prinsip ini, kaum pluralis beranggapan bahwa, karena berbagai pelayanan dan kegiatan pemerintah dibiayai warga negara, maka adalah hak warga untuk ikut mengelola didalamnya. ${ }^{13}$

Bagi kaum pluralis, negara dilihat sebagai arena terjadinya konflik diantara departemen dalam sebuah pemerintahan yang merepresentasikan adanya jarak diantara kelompok kepentingan. Sebuah otoritas bisa saja menjadi hilang dalam sebuah pemerintahan, dikarenakan tiadanya satu kepentingan yang mampu mendominasi negara. David Easton, sebagaimana dikutip Marsh, percaya bahwa kebijakan muncul dari adanya interaksi beragam elemen sosial. Politik sebagai kepentingan resolusi konflik bermakna bahwa semua kelompok adalah elemen penting dalam proses politik. Karena itu, proses kebijakan, pada dasarnya adalah proses konflik dan pertukaran yang terus menerus diantara berbagai kelompok dengan pemerintah. Kaum pluralis mendefinisikan negara sebagai organisasi pembuat kebijakan khusus yang merespon tuntutan berbagai kelompok kepada pemerintah. ${ }^{14}$

Aliran pluralisme mencerminkan keanakaragaman segi politik. Pertanggungan jawab dan persetujuan ditebarkan ke seluruh masyarakat. Kedaulatan bagi pemerintahan yang berbentuk parlementer atau presidensial, merupakan milik banyak orang. Bentuk pemeriuntahan semacam itu bertentangan dengan struktur monistic, yang memusatkan kekuasaan pada jabatan tertinggi politik sehingga sasaran dan tujuan kekuasaan dibatasi menurut kehendak yang menggenggamnya. Monisme merupakan paham yang terkait dengan otokrasi, totalitarianisme dan otoritarianisme. Sedangkan pluralisme bertaut dengan demokrasi. Jelasnya, makin tinggi pluralisme, makin berkembang demokrasi. ${ }^{15}$

12 Martin Smith, "Pluralism" dalam David Marsh dan Gerry Stoker (eds), Theory and Methods in Political Science, (Basingstoke: Macmillan, 1995), hal 209-210.

13 David E. Apter, Pengantar, hal 452.

14 Martin Smith, "Pluralism", hal, 211.

15 David E. Apter, Pengantar, hal 458. 
Yang perlu dicermati, pokok teori kaum pluralis tidak hanya menetapkan bagaimana kekuasaan dibagi dan dialokasikan, tetapi bagaimana di dalam proses tindakan politik, pilihan sosial yang ada diperkuat. Pada prinsipnya, pluralisme menetapkan metode yang memungkinkan semua pemeran serta -individu, kelompok, badan pemerintah pada semua tingkat, badan perorangan- satu sama lain secara berkesinambungan mengaji keuntungan dan kerugian relatif. Melalui kegiatan ini dan hasil-hasilnya, pilihan sosial akan memberi sistem politik arti yang penting. ${ }^{16}$

Dalam konteks penyaluran aspirasi kelompok tersebut, peranan partai politik menjadi amat penting. Politik partai merupakan faktor yang penting bagi pemenuhan kepentingan kelompok masyarakat yang majemuk. Partailah yang menyampaikan informasi rakyat kepada pemerintah, mengartikulasikan kepentingan dan merekrut para calon untuk jabatan politik. Sebaliknya, dari sudut umpan balik, partai politik ini membantu memastikan bahwa pembuatan peraturan legislatif sudah tepat dan bisa diterapkan dengan baik. ${ }^{17}$

Terkait dengan pendekatan pluralisme politik dalam kebijakan publik, ada beberapa pertanyaan kunci yang akan memandu peneliti dalam studi ini. Pertanyaan penting dalam pendekatan pluralisme adalah; siapa yang terlibat dalam proses pembuatan keputusan; pilihan siapa yang diterima sebagai sebuah keputusan; dan siapakah yang bisa memberi pengaruh terhadap hasil (outcomes) keputusan. ${ }^{18}$

Lantas, apa keuntungan yang bisa diperoleh dengan pendekatan pluralisme politik ini? Argumentasi yang bisa diajukan adalah karena asumsi pendekatan ini adalah distribusi kekuasaan. Melalui pendekatan ini, sangat memungkinkan untuk menentukan, secara empiris, siapa yang memperoleh kekuasaan dan siapa yang tidak. Dengan mengembangkan ide tentang masyarakat dan negara modern yang terbagibagi, beragam, dan demokratis, kaum pluralis menyediakan deskripsi yang lebih akurat tentang distribusi kekuasaan daripada monolitik ala marxis atau teori elit. ${ }^{19}$

\section{Syariat Islam di Indonesia Pasca Orde Baru; dari Pusat ke Pinggiran}

Kampanye penarapan Syariat Islam di Indonesia setelah tumbangnya orde baru mulai marak pada sidang tahunan MPR tahun 2000 dan 2001. Pada saat itu,

\footnotetext{
16 David E. Apter, Pengantar, hal 522.

Ibid., hal 523.

18 Martin Smith, "Pluralism," hal 213-214.

19 Ibid., hal 214.
} 
beberapa partai berasas Islam, seperti PPP, PBB, dan PK, mengajukan proposal pencantuman kembali tujuh kata Piagam Jakarta dalam amandemen UUD 1945. Tetapi, upaya ini mengalami kegagalan sekalipun didukung kelompok radikal Islam yang menggelar demonstrasi di depan gedung parlemen. Selain fraksi-fraksi di MPR, penolakan juga dilakukan dua ormas Islam terbesar di Indonesia; NU dan Muhammadiyah. ${ }^{20}$

Seolah tak kenal lelah, dalam sidang tahunan MPR 2002, PPP, PBB, dan PK kembali memperjuangkan pencantuman tujuh kata Piagam Jakarta dalam Amandemen UUD 1945. Langkah ketiga partai ini mendapat dukungan partaipartai kecil Islam yang tidak berhasil memperoleh kursi parlemen. Partai-partai ini hanya bisa memperjuangkan formalisasi Syariat Islam dari luar parlemen. Tetapi, PPP dan PBB yang pada mulanya ngotot dengan gagasan tersebut, akhirnya mencabut usulannya. Akibatnya, PK menilai PPP dan PBB tidak serius memperjuangkan gagasan penarapan Syariat Islam. ${ }^{21}$

Bagaimana sikap pemerintah saat itu, terutama Presiden dan Wapres, sebagai otoritas tertinggi pembuat kebijakan publik, dalam menyikapi tuntutan penerapan Syariat Islam dari kelompok-kelompok tertentu? Di satu sisi, tidak ada sikap resmi dari Presiden terhadap isu krusial ini. Di sisi lain, Wakil Presiden era Megawati yakni Hamzah Haz dan Menteri Kehakiman dan HAM saat itu Yusril Ihza Mahendra, sering mengemukakan pernyataan-pernyataan kontroversial terkait isu formalisasi Syariat Islam di Indonesia. ${ }^{22}$

Pada penghujung tahun 2001, dalam salah satu kunjungannya ke Manado, Wapres Hamzah Haz yang saat itu juga Ketua Umum PPP, menjanjikan bahwa Piagam Jakarta tidak akan masuk dalam Pembukaan UUD 1945, karena telah menjadi komitmen para pendiri Indonesia masa lalu. Namun di lain kesempatan, ia membantah dirinya tidak konsisten dalam perjuangan PPP untuk memasukkan Syariat Islam dalam amandemen pasal 29 UUD $1945 .^{23}$

20 Taufik Adnan Amal dan Samsu Rijal Panggabean, Politik Syariat Islam, hal 62. Selain partai politik, kelompok Islam Militan juga melakukan tekanan politik agar Piagam Jakarta dimasukkan dalam Amandemen UUD 1945. S. Yunanto, et. Al., Gerakan Militan Islam, hal 44.

21 Taufik Adnan Amal dan Samsu Rijal Panggabean, Politik Syariat Islam, hal 62-63. Lihat pula, Wahyuddin Halim, "Gerakan Formalisasi," hal 129. Perdebatan-perdebatan seputar Syariat Islam terkait upaya memasukkan tujuh kata Piagam Jakarta dalam Amandemen UUD 1945 dapat pula dibaca dalam, Kurniawan Zein dan Saifuddin HA (ed)., Syariat Islam Yes, Syariat Islam No; Dilema Piagam Jakarta dalam Amandemen UUD 1945, (Jakarta: Paramadina, 2001).

22 Taufik Adnan Amal dan Samsu Rijal Panggabean, Politik Syariat Islam, hal 64.

23 Ibid. 
Yang tidak kalah tegas adalah pernyataan dari Menkeh dan HAM, Yusril Ihza yang saat itu juga Ketua Umum PBB. Dalam sejumlah kesempatan ia mengemukakan bahwa KUHAP (Kitab Undang-Undang Hukum Pidana) yang berdasarkan Syariat Islam akan segera diberlakukan di Indonesia untuk mengganti KUHP produk Belanda yang masih berlaku saat ini. Ketika berkunjung ke Pamekasan, Yusril menyatakan bahwa rancangan KUHP bermuatan Syariat telah selesai digarap dan tinggal menunggu pengesahannya ke lembaga legislatif yang direncanakan pada pertengahan 2003. Ketika berceramah di Universitas Magelang Muhammadiyah pada akhir September 2002, hal yang sama juga dilontarkan Yusril. Tetapi, hingga Pemilu Legislatif dan Pemilu Presiden pada 2004 lalu, rancangan KUHP bermuatan Syariat itu tak kunjung dibahas parlemen. ${ }^{24}$

Dalam konteks nasional, gerakan Islam yang memperjuangkan syariat Islam di Indonesia bertindak dalam dua pola; pola kekuasaan politik dan pola kultural menuju kekuasaan. Hal ini bisa disimak dari gerakan mereka yang memperjuangkan syariat Islam dengan melakukan lobi-lobi kekuasaan (DPR, MPR, dan partai politik) dan mereka yang mendakwahkan di masyarakat dengan strategi menguasai masyarakat terlebih dahulu baru kemudian mengislamkan kekuasaan. ${ }^{25}$

FPI, KISDI, dan Majelis Mujahidin menggunakan pola yang pertama; dengan menggelar aksi dukungan kepada partai-partai politik yang memperjuangkan syariat Islam (dari kekuasaan ke masyarakat). Sehingga gerakannya lebih politis, seperti aksi demonstrasi atau unjuk rasa ke senayan. Bahkan, Majelis Mujahidin sudah membuat amandemen UUD 1945 yang sesuai dengan syariat Islam. Sementara Laskar Jihad menggunakan strategi kedua; yakni memberikan dakwah Islam kepada masyarakat agar terjadi proses Islamisasi masyarakat secara menyeluruh (dari masyarakat ke kekuasaan), sehingga mereka tidak mau melakukan demonstrasi sebagai bentuk gerakan aspirasi. Karena bagi mereka, masyarakat itulah yang menjadi sasaran dakwah Islam, bukan negara. Nah, ketika masyarakat sudah menyadari kewajiban memberlakukan syariat Islam, maka secara otomatis negara harus mengikuti keinginan masyarakat. Dua pendekatan inilah yang sedang dimainkan oleh kelompok-kelompok Islam militan di Indonesia dengan satu tujuan memberlakukan Syariat Islam. ${ }^{26}$

Ibid., hal 64-65.

25 Khamami Zada, "Wacana Syariat Islam," hal 32.

26 Ibid., hal 32-33. 
Namun demikian, kegagalan perjuangan formalisasi Syariat Islam di tingkat pusat tidak berarti "mematikan" gerakan penarapan Syariat Islam di wilayah Indonesia. Buktinya, sejak kegagalan di sidang MPR tahun 2002, tuntutan di luar sidang semakin menguat. Sejak saat itu, sejumlah provinsi menuntut pemberian status otnomi khusus dari pemerintah dan DPR untuk daerah mereka sehingga Syariat Islam dapat diberlakukan secara khusus di daerah mereka masing-masing. Daerah pertama yang telah mendapatkan otonomi khusus adalah Aceh. Otonomi ini menyangkut otoritas untuk menetapkan peraturan-peraturan (qanun) yang diperlukan dalam provinsi tersebut berdasarkan Syariat Islam. ${ }^{27}$

Hal ini, boleh jadi, merupakan dampak lain dari dilaksanakannya kebijakan otonomi daerah sejak tahun 2001. Pasca otonomi daerah tersebut, aspirasi untuk menerapkan Syariat Islam secara penuh mulai menyeruak. Undang-undang otonomi daerah yakni UU 22/1999 dijadikan landasan konstitusional dalam formalisasi Syariat Islam. Menjelang akhir 2004, selain Aceh yang dipandang membuka jalan bagi daerah lain untuk menuntut otonomi khusus, propinsi atau daerah lain yang berjuang keras menerapkan Syariat Islam di daerah masing-masing adalah Sulawesi Selatan, Cianjur dan Tasikmalaya (dua kota di Jawa Barat), Banten, Sumatera Barat, dan Kalimantan Selatan. ${ }^{28}$ Hingga tahun 2006, tercatat sekitar 22 kota dan kabupaten yang memberlakukan perda SI tersebut. ${ }^{29}$

Lantas bagaimana geliat Syariat Islam di aras lokal? Bagaimana wujud perjuangan penerapan Syariat Islam di tingkat daerah? Bagaimana kebijakan untuk memformalisasikan Syariat Islam didesakkan? Berikut ini akan dipaparkan beberapa daerah yang getol memformalisasikan Syariat Islam.

Di beberapa daerah di Indonesia, tuntutan formalisasi Syariat Islam banyak digerakkan oleh kelompok-kelompok Islam lokal. Hal ini dipicu karena ada keinginan untuk mereplikasi otonomi khusus yang diperoleh Aceh sehingga punya otoritas untuk menerapkan Syariat Islam. Dari beberapa penelusuran, semangat pemerintah darah untuk mengakomodasi formalisasi Syariat Islam menjadi peraturan daerah (perda) atau sekedar surat edaran, lebih merupakan tekanan dari unsurunsur dalam masyarakat lokal. Berikut ini adalah gambaran umum dari beberapa daerah yang selama ini menggemakan Syariat Islam.

27 Taufik Adnan Amal dan Samsu Rijal Panggabean, Politik Syariat Islam, hal 12-54.

28 “Gairah Syariat Islam di Berbagai Daerah,” Suara Hidayatullah, Juli 2000.

29 Tempo, 14 Mei 2006, hal 29. 
Nanggroe Aceh Darussalam (NAD) boleh jadi merupakan daerah yang paling siap menjalankan Syariat Islam. Tuntutan sebagian masyarakat untuk memformalisasikan Syariat Islam dalam pranata negara direspon pemerintah pusat dengan mengundangkan UU No. 44/1999 tentang penyelenggaraan keistimewaan Provinsi Daerah Istimewa Aceh. Berpijak pada konstitusi tersebut, lahirlah berbagai peraturan daerah seperti Perda No. 3/2000 tentang Majelis Permusyawaratan Ulama, Perda No. 5/2000 tentang pelaksanaan Syariat Islam, dan beberapa perda terkait.Pemprov NAD juga membentuk Bagian Syariat Islam di Kantor Gubernur dan Bappeda propinsi. ${ }^{30}$

Selain Aceh, Sulawesi Selatan tampaknya menjadi daerah yang paling siap memformalisasikan Syariat Islam. Menurut sebuah survei yang dilakukan Pemprov Sulsel pada januari 2003, sekurang-kurangnya 20 dari 24 Bupati Kepala Daerah di provinsi itu telah mengungkapkan kesanggupan mereka untuk menerapkan Syariat Islam di daerah masing-masing. ${ }^{31}$

Kesiapan ini dibuktikan dengan adanya Komite Persiapan Penegakan Syariat Islam (KPPSI) yang kemudian menjadi Komite Penegakan Syariat Islam (KPSI). Kelompok ini didukung oleh berbagai elemen masyarakat, intelektual, ulama dan tokoh penting masyarakat Sulawesi Selatan, seperti Achmad Ali dari Univ. Hasanuddin, K.H. Sanusi Baso, Ketua MUI Sulsel, Jusuf Kalla, Tamsil Linrung, A.M. fatwa dan lain-lain. Pada 15 April 2001, KPSI mengeluarkan Deklarasi Muharram yang antara lain mendesak DPRD Sulsel untuk menindaklanjuti tuntutan otonomi khusus Prov. Sulsel.selain itu, KPSI juga mendatangi DPR RI dan menyampaikan aspirasinya mengenai penegakan Syariat Islam di Sulsel. ${ }^{32}$

Selama beberapa tahun perjuangannya, KPSI berhasil menghimpun pemimpinpemimpin Ormas Islam garis keras dan lunak, para intelektual dan aktivis-aktivis Sulsel. Bahkan kelompok ini telah mendapat rekomendasi dari jajaran pemerintah dan dewan legislatif lokal, serta sejumlah pemimpin cabang partai politik lokal. Bahkan, Gubernur Sulsel H.Z.B Palaguna dan Ketua DPRD Sulsel, Amin Syam,

30 Taufik Adnan Amal dan Samsu Rijal Panggabean, Politik Syariat Islam, hal 25-28.

31 “91,11 persen Setuju Syariat Islam -Hasil Jajak Pendapat Pemprov Sulsel," Fajar, 27 Januari 2003. Lihat pula Wahyuddin Halim, "Gerakan Formalisasi Syariat,” hal 130.

32 Taufik Adnan Amal dan Samsu Rijal Panggabean, Politik Syariat Islam, hal 82-84. Tentang gerakan KPPSI ini juga bisa dilihat pada Wahyuddin Halim, "Gerakan Formalisasi Syariat Islam melalui Instrumen Negara; Refleksi Kritis atas KPPSI," dalam Kamaruddin Amin, dkk., Quo Vadis Islamic Studies in Indonesia? (Current Trends and Future Challanges), (Makasar: PPs UIN Alauddin Makassar, 2006), hal 125-152. 
dalam rangka menyampaikan tuntutan KPSI telah menyampaikan proposal otonomi khusus Sulsel dalam rangka penerapan Syariat Islam ke Jakarta. Selain itu, pemda Sulsel bersama KPSI telah membentuk tim untuk mengkaji rencana pemberlakuan Syariat Islam. ${ }^{33}$

Salah satu wilayah di Sulsel yang cukup getol menerapkan Syariat Islam adalah Bulukumba. Di sana terdapat 4 aturan Syari'at Islam yang disahkan sebagai Perda, yaitu Perda Minuman Keras; Zakat, Infak dan Shadaqah; Baca Tulis al-Qur'an bagi Siswa dan Calon Pengantin; dan Pakaian Muslim dan Muslimah. Bahkan di atas pintu masuk rumah A. Rukman A Jabbar, Kepala Desa Padang, salah satu desa di kecamatan Gantarang Bulukumba jelas tertulis: "Maaf tidak melayani tamu wanita yang tidak berjilbab." Tidak hanya itu, desa Padang juga sedang giat-giatnya menerapkan aturan berdasarkan syariat Islam yang terlihat melalui berbagai hal yang berbau Arab, seperti kantor kepala desa, papan nama di setiap rumah dan nama jalan yang seluruhnya menggunakan bahasa Arab, dengan menggunakan tulisan berwarna putih dengan dasar hijau. ${ }^{34}$

Di Riau, aspirasi untuk menerapkan Syariat Islam disuarakan oleh peserta musyawarah kerja wilayah II PPP Riau pada 17-18 April 2001 yang dibuka Ketua Umum PPP saat itu Hamzah Haz. Alasan tuntutan pemberlakukan Syariat Islam adalah karena sebagian besar masyarakat Riau adalah keturunan Melayu dan pemeluk Islam. ${ }^{35}$

Upaya penerapan Syariat Islam lagi-lagi dimotori partai politik. Di Banten, upaya ini mendapat dukungan dari partai politik Islam, salah satunya adalah Partai Keadilan Kab. Serang. Pada 23 Juni 2002, DPD PK Serang menyelenggarakan suatu musyawarah untuk menggagas penegakan Syariat Islam di Prov. Banten. Hasil lokakarya tersebut, diantaranya adalah pembentukan KPPSIB (Komite Persiapan Penegakan Syariat Islam Banten) dan sejumlah rancangan peraturan daerah bernuansa Syariat. ${ }^{36}$

Sementara di Cianjur Jawa Barat, ide pemberlakukan Syariat Islam dikemukakan oleh Bupati Cianjur Wasidi Swastomo saat memperingati Tahun Baru Islam 1

33 Taufik Adnan Amal dan Samsu Rijal Panggabean, Politik Syariat Islam, hal 84-85.

34 Nurlis E. Meuko dan Irmawati, "Pecut Bambu Dari Bulukumba," dalam Tempo, 14 Mei 2006, hal 33. Uraian lebih lengkap tentang sejarah Bulukamba, pluralitas masyarakatnya dan perda Syariat Islam di Bulukamba bisa dilihat pada, Syamsurijal Ad'han dan Zubair Umam, "Perdaisasi Syariat Islam di Bulukumba," dalam Jurnal Tashwirul Afkear, Edisi No. 20 Tahun 2006. hal 56-77.

35 Taufik Adnan Amal dan Samsu Rijal Panggabean, Politik Syariat Islam, hal 87-88.

36 Ibid., hal 88. 
Muharram $1422 \mathrm{H}$ yang bertepatan pada 26 Maret 2001 di Alun-alun Cianjur. Di hadapan ratusan jamaah dan puluhan aktivis LSM Islam garis keras, Wasidi mencanangkan Cianjur sebagai daerah yang akan melaksanakan Syariat Islam dengan segala aspeknya. Hal ini merupakan gerakan moral dan dakwah untuk mewujudkan komunitas muslim yang memiliki sikap dan prilaku islami dalam bingkai negara kesatuan Republik Indonesia (NKRI). ${ }^{37}$ Selain itu, Bupati Cianjur, Wasidi, juga menerbitkan surat keputusan (SK) Bupati No. 34/2001 tentang pembentukan Lembaga Pengkajian Pengembangan Islam (LPPI). Tugas lembaga ini adalah menyusun konsep-konsep pelaksanaan Syariat Islam di Cianjur. ${ }^{38}$

Di Jawa Barat, kota Tasikmalaya juga terlihat getol menerapkan Syariat Islam. Di kota ini, salah satu kelompok yang bersemangat menerapkan Syariat Islam adalah Brigade Taliban. Selain giat mengadakan pemusnahan minuman keras dan pembersihan pelacuran, kelompok ini juga memblokir jalan pada hari Jumat. Hal ini dilakukan untuk menjaka ketenangan sholat Jumat dan mengingatkan kaum laki-laki yang lalai untuk menunaikan sholat Jumat. Di samping Brigade Taliban, di Tasikmalaya juga ada Gerakan Pemuda Islam (GPI) yang dipimpin Agus Salim. Kelompok ini dalam sejumlah kesempatan telah mendesak pemda dan DPRD setempat untuk mengundangkan perda anti-miras dan perjudian. ${ }^{39}$ Kelompok lainnya adalah Forum Silaturrahmi Pemuda Jalanan Tasik. Salah satu anggota Presidium yakni Tb Miftah Fauzi menyatakan, Syariat Islam merupakan jawaban dari persoalan berat yang selama ini mendera Tasikmalaya. ${ }^{40}$

Sementara di Indramayu, upaya memformalisasikan Syariat Islam datang dari Bupati Indramayu, Yance Irsyam. Pada November 2002, Yance mengumumkan berlakunya sebagian Syariat Islam di Indramayu. Pengumuman ini dikemukakan dalam sebuah rapat paripurna DPRD Indramayu, bertepatan dengan ulang tahun ke- 475 kota tersebut. Sebagai langkah awal penerapan Syariat Islam, Bupati mengharuskan PNS perempuan memakai jilbab dan PNS laki-laki memakai baju koko setiap hari Jumat. Selain itu, kegiatan kantor harus dihentikan 20 menit di

37 Taufik Adnan Amal dan Samsu Rijal Panggabean, Politik Syariat Islam, hal 89-90.

38 "Rame-rame Formalisasi Syariat Islam," Halqoh, Edisi XVI/2002, hal 7.

39 Taufik Adnan Amal dan Samsu Rijal Panggabean, Politik Syariat Islam, hal 92.

40 "Rame-rame Formalisasi Syariat Islam," Halqoh, Edisi XVI/2002, hal 7. Gempita Syariat Islam di Tasikmalaya juga bisa dibaca pada, Anom SP, "Gempa Tektonik Syariat Islam di Daerah; Mengungkap Rencana Strategis 2001-2005 di Tasikmalaya,” Jurnal Tashwirul Afkar, Edisi No. 12/ 2002, hal 85-96. 
saat waktu Dhuhur dan Asar tiba untuk memberi waktu sholat kepada pegawai yang hendak menunaikan sholat. Selain itu, sebelum memulai pekerjaan, para pegawai diwajibkan membaca Al- Qur an. Bupati juga mengeluarkan imbauan agar para pegawai berpuasa Senin dan Kamis. ${ }^{41}$

Di Pamekasan-Jawa Timur, sosok Bupati lagi-lagi menjadi aktor utama upaya memformalisasikan Syariat Islam. Pada awal November 2002, Pamekasan mendeklarasikan penerapan Syariat Islam. Adalah Dwiatmo Hadiyanto, Bupati Pamekasan, yang mendeklarasikan pemberlakuan Syariat Islam di masjid agung AlSyuhada. Deklarasi ini disusul dengan adanya surat edaran Bupati ke berbagai instansi pemerintah dan lembaga pendidikan dengan himbauan agar para pegawai mengenakan busana muslim, memberi waktu jeda untuk sholat secara berjamaah dan himbauan lainnya. Tetapi, himbauan ini kurang mendapat tanggapan dari para pegawai, meski Bupati telah membentuk Lembaga Pengkajian dan Penerapan Syariat Islam. ${ }^{42}$

Dari geliat perjuangan formalisasi Syariat Islam pasca Orde Baru, terlihat adanya dua jalur penting yang digunakan kelompok pendukung formalisasi Syariat Islam. Pertama, jalur parlemen pusat. Jalur ini digunakan pendukung penerapan Syariat Islam di Indonesia pada kurun 2000-2002. Ini terlihat terutama ketika sidang tahunan MPR berlangsung di mana wacana kembalinya tujuh kata dalam Piagam Jakarta selalu digaungkan untuk masuk dalam amandemen UUD 1945.

Kedua, jalur parlemen lokal, partai politik lokal dan birokrasi daerah terutama kepala daerah. Jalur ini menjadi primadona kelompok pendukung formalisasi Syariat Islam yang dipakai di daerah-daerah. Hal ini terlihat pasca kegagalan memasukkan Piagam Jakarta dengan tujuh katanya dalam amandemen UUD 1945. Seolah hendak “mengepung” Jakarta, wacana penarapan Syariat Islam digulirkan ke berbagai daerah terutama yang mayoritas warganaya beragama Islam.

\section{Jejak Suara Kaum Minoritas di Balik Gempita Syariat Islam di Indonesia}

Terhadap wacana Syariat Islam di Indonesia, banyak suara-suara yang muncul merespon. Dari penelusuran yang dilakukan penulis, respon terhadap persoalan ini muncul dari kelompok non-muslim serta kalompok muslim moderat. Hanya saja, gaung dari suara-suara ini memang tidak begitu nyaring.

\footnotetext{
41 Taufik Adnan Amal dan Samsu Rijal Panggabean, Politik Syariat Islam, hal 94.

${ }^{42}$ Ibid. Lihat pula "Rame-rame Formalisasi Syariat Islam," Halqoh, Edisi XVI/2002, hal 8.
} 
Salah satu kelompok yang merespon isu formalisasi Syariat Islam adalah Partai Damai Sejahtera (PDS). PDS menilai, sejumlah peraturan daerah — yang substansinya menegakkan moralitas bangsa-tidak bisa dilakukan. Mereka menggalang anggota lintas fraksi di DPR yang beragama Kristen untuk menuntut pemerintah mencabut semua perda 'islami'. Anggota DPR yang menandatangani penolakan sebanyak 56 orang. Mayoritas dari Fraksi PDS dan PDIP, tapi beberapa anggota Fraksi Partai Golkar dan Fraksi PKB ikut bergabung. "Kami minta pimpinan DPR menyurati Presiden untuk mencabut perda-perda tersebut," kata ketua Fraksi PDS, Constant Ponggawa didampingi Nusron Wahid (FPG) saat menemui Wakil Ketua DPR saat itu yakni Soetardjo Soerjogoeritno (Fraksi PDIP).

Suhadi berpendapat, pada kenyataannya, perda-perda Syariat Islam menyimpan banyak masalah, baik dari sisi proses penyusunan sampai akibatnya. Misalnya, pemerintah daerah Indramayu di Jawa Barat mengidentifikasi salah satu masalah sosialnya adalah banyaknya perempuan pergi ke luar negeri menjadi pelacur, sebuah asumsi yang masih perlu dikaji. Dengan demikian, untuk mengatasi masalah itu, Pemda merasa perlu menyusun aturan kewajiban kemampuan baca al-Qur'an untuk siswa, susuatu yang sulit dicari logikanya. ${ }^{43}$

Suhadi menandaskan, sangat penting menempatkan kenyataan bahwa banyak kalangan Muslim yang tidak sepakat penerapan perda seperti itu dan tidak harus dipandang kurang keberislamanya. Umat Islam bisa tetap menjalankan Syariat Islam, tapi tidak harus meminta negara sebagai elemen pemaksanya. Sebab aturan tersebut tidak saja menyisakan banyak pertanyaan mengenai posisi 'minoritas', tapi juga keragaman umat Islam di Indonesia. Kalau peraturan seperti ini berkembang terus, mungkin akan ada usaha menunggalkan wajah Islam di Indonesia. ${ }^{44}$

Sementara Ketua DPD PDKB (Partai Demokrasi Kasih Bangsa) Sulawesi Utara, Elisabeth Winokan, dengan tegas menolak diberlakukannya "tujuh kata" Piagam Jakarta dalam dalam UUD 45. "PDKB tetap konsisten dan tidak akan berubah dalam menolak Syariat Islam," ujar Winokan. Ia menyatakan, PDKB akan berada di garda terdepan menentang tujuh kata ini bila ada kalangan-kalangan tertentu yang mau memaksakan dimasukkan ke dalam UUD $45 .{ }^{45}$

43 Suhadi Cholil, "Perda Syariat di Negeri Pancasila," dalam wwm.parasindonesia.com. Diakses pada 9 Februari 2007.

44 Ibid.

45 "Pdt Gara: Hormati Kebebasan Berpendapat," Manado Post, 29 Agustus 2001. 
Sementara itu, Pendeta Dr Nico Gara mengaku tak bisa memberi tanggapan banyak soal aksi sejumlah ormas Islam yang melakukan aksi di gedung DPR-RI Senayan Jakarta mendesak mengagendakan Piagam Jakarta dalam sidang tahunan MPR. Lelaki yang juga dikenal mantan pimpinan Pemuda Sinode GMIM dan aktivis GMKI ini, mengaku hanya bisa memberi tanggapan atas pribadinya sendiri, dan bukan sebagai Sekretaris Umum Badan Pekerja Sinode Gereja Masehi Injili di Minahasa. Baginya, persoalan desakan sejumlah Ormas Islam itu, merupakan hak mereka yang juga warga negara Indonesia dalam mengeluarkan pendapat. "Kita harus menghormati kebebasan mengeluarkan pendapat sebagai sesama warga negara," kata Pdt Gara. Namun ia menyarankan agar kita tidak usah khawatir dan mempercayakan saja persoalan itu kepada MPR. 'Itu kan harus ditetapkan di MPR. Dan tentunya yang kita harapkan dan perlu kita ingatkan kepada MPR, kalau masih ingin menghendaki adanya negara kesatuan republik Indonesia, bhineka tunggal ika jangan hanya lips service," sarannya. ${ }^{46}$

Terkait kebijakan Bupati Cianjur, Wasidi Swastomo, untuk menjalankan syariat Islam kepada PNS, Wakil Ketua DPC PDIP Cianjur, Dadang Solehudin menyatakan, kebijakan Bupati tersebut menimbulkan sejumlah tafsiran dan ekses tidak sehat di masyarakat. Baginya, sebagai pejabat publik, bupati tidak bisa berpikir sekterian. ${ }^{47}$

Dari Manado, Ketua Pemuda Gereja Masehi Injili di Minahasa, Ir. Hanny Pua sangat menyesalkan tindakan Bupati Cianjur tersebut. Menurut Hanny Pua, ide pemberlakuan syrariat Islam ataupun Piagam Jakarta sebenarnya sudah final yakni ditolak karena tidak sesuai dengan komitmen para pendiri bangsa yang terwujud dalam Pancasila. Tapi, kalau kemudian ada pihak, kelompok ataupun golongan tertentu yang mengungkit-ungkit kembali, sama seperti dengan menciptakan potensi perpecahan bangsa. Menurut Hanny Pua, ketua Kongres Minahasa Raya, rakyat Minahasa lewat Kongres Minahasa Raya sudah dengan tegas menunjukkan sikapnya yaitu tidak setuju dengan pemberlakuan Syariat Islam ataupun Piagam Jakarta. ${ }^{48}$

Protes keras juga ditunjukan Ketua Dewan Pimpinan Daerah Partai Kristen Indonesia (Parkindo) Sulawesi Utara, Richard Rengkung. Menurutnya, tindakan bupati

46 "Pdt Gara: Hormati Kebebasan Berpendapat," Manado Post, 29 Agustus 2001.

47 "Minahasa Kecam Pemberlakuan Syariat Islam di Jawa," Manado Post, 29 Agustus 2001.

48 "Minahasa Kecam Pemberlakuan Syariat Islam di Jawa," Manado Post, 29 Agustus 2001. 
Cianjur tersebut masuk dalam kategori subversi. Alasannya, pemberlakuan Syariat Islam ataupun piagam Jakarta akan menimbulkan kemungkinan perpecahan bangsa, itu sama dengan tindakan subversi, mengancam persatuan dan kedaulatan negara. ${ }^{49}$

Ide menerapkan Syariat Islam di Tasikmalaya ternyata tidak didukung sepenuhnya dari parlemen. Ade Kamaluddin, anggota DPRD Tasikmalaya dari FPP, menyatakan pesismis hal itu bisa terwujud. Menurut Ade, hukum apapun yang ingin ditegakkan secara formal tidak bisa sesuai yang dikehendaki umat Islam Tasikmalaya, karena dianggap bertentangan dengan undang-undang yang berlaku. ${ }^{50}$

Marzuki Wahid menilai, sejauh ini kalangan non-muslim sebetulnya merasa ketakutan untuk merespon. Ia menduga sebetulnya kalangan non-muslim tidak setuju dengan formalisasi Syariat Islam. Ia juga melihat bahwa kalangan non-muslim ini ketakutan untuk bereaksi, karena tekanan yang luar biasa dari kalangan muslim tertentu. Hal ini membuat kalangan non-muslim melakukan peminggiran sendiri dan bersikap defensif. Kalaupun kalangan non-muslim bersuara terkait wacana Syariat Islam, ujar Marzuki, hal itu seolah-olah tidak berarti karena kalah dengan arus dominan yang menghendaki Syariat Islam. ${ }^{51}$

\section{E. Kebijakan Syariat Islam di Indonesia; Perspektif Pluralisme Politik}

Dari pemaparan di atas, penulis telah memotret pola perjuangan formalisasi Syariat Islam di Indonesia pada masa reformasi, jalur yang ditempuh hingga suarasuara kaum minoritas terkait formalisasi Syariat Islam tersebut. Dalam sub bab ini, penulis akan membahas upaya formalisasi Syariat Islam melalui instrumen negara dari sudut pandang pluralisme politik.

Pertama, adanya kebijakan beberapa pemerintah daerah yang mengakomodasi Syariat Islam dalam bentuk perda, surat edaran, surat keputusan bupati dan sebagainya, sebagaimana disinggung di atas, jelas akan memberi peran berlimpah terhadap komunitas masyarakat tertentu, dalam hal ini komunitas pendukung Syariat Islam. Di sisi lain, kelompok yang kontra formalisasi Syariat Islam akan merasa tersisihkan dan menjadi warga non-partisipan dalam sebuah kebijakan publik di suatu daerah.

49 Ibid.

50 “Rame-rame Formalisasi Syariat Islam," Halqoh, Edisi XVI/2002, hal 8.

51 Wawancara dengan Marzuki Wahid, "Syariat Islam Butuh Reinterpretasi," dalam Halqoh, Edisi XVI/2002, hal 17. 
Kedua, kebijakan formalisasi Syariat Islam dalam sebuah pemerintah menegakan telah terjadinya dominasi aspirasi satu kelompok dalam suatu kebijakan publik. Seperti telah dijelaskan, pluralisme politik meyakini bahwa dalam proses pembuatan kebijakan publik, semua kelompok memiliki akses dan suara yang sama. Selain itu, kaum pluralis meyakini bahwa negara atau pemerintah adalah organisasi pembuat kebijakan yang mampu merespon tuntutan berbagai kelompok. Dalam konteks ini, pemerintah harus memfasilitasi akses tersebut dan memberi peluang yang bagi setiap kelompok untuk berpendapat dalam suatu kebijakan publik.

Sayangnya, di beberapa daerah, seperti Cianjur, Indramayu dan Pamekasan, pemerintah, dalam hal ini Bupati, justru menjadi aktor utama tersumbatnya akses dan partisipasi suatu kelompok dalam proses formulasi kebijakan publik, dalam hal ini kebijakan yang mendasarkan pada agama tertentu. Padahal, semestinya seorang Bupati sebagai representasi pemerintah menjadi institusi yang mampu menyerap dan merumuskan aspirasi semua kelompok masyarakat di wilayahnya.

Ketiga, selain itu, dalam konteks formalisasi Syariat Islam, partai politik belum bisa menempatkan diri sebagai penyalur aspirasi semua kelompok masyarakat. Politik partai merupakan faktor yang penting bagi pemenuhan kepentingan kelompok masyarakat yang majemuk. Partai politik merupakan institusi politik yang menyampaikan informasi rakyat kepada pemerintah dan mengartikulasikan kepentingan semua kelompok kepada pemerintah.

Di beberapa daerah, semisal Riau dan Banten, partai politik justru menjadi penyalur aspirasi kelompok tertentu, dalam hal ini kelompok yang menghendaki formalisasi Syariat Islam. Hal ini tentu tidak sejalan dengan fungsi partai politik yang idealnya mampu menjadi sarana partisipasi semua kelompok masyarakat.

Keempat, kebijakan publik berupa perda Syariat Islam dan sebagainya memperlihatkan betapa kekuasaan politik tidak terdistribusi secara merata kepada semua kelompok masyarakat yang ada. Di beberapa daerah, seperi Aceh, Sulawesi Selatan dan Tasikmalaya, kelompok masyarakat tertentu terlihat mendominasi kekuasaan politik dan kurang memberi ruang bagi kelompok masyarakat lain untuk bisa bersuara.

Dilihat dari kaca mata pluralisme politik, hal ini tentu bertolak belakang. Dalam pluralisme politik, kekuasaan harus bisa diakses oleh setiap kelompok yang ada dan tidak didominasi oleh kelompok tertentu. Hal ini karena pluralisme politik percaya bahwa semakin kekuasaan terdistribusi, maka semakin demokratis sebuah pemerintahan. 
Dalam negara yang menganut sistem demokrasi seperti Indonesia, di mana hak berpendapat sangat dihormati dan dijunjung tinggi, aspirasi suatu kelompok masyarakat untuk menerapkan Syariat Islam bukanlah sesuatu yang salah. Hal ini harus dihormati dan diberi ruang untuk berekspresi.

Kebijakan otonomi daerah dan desentralisasi yang digulirkan sejak tahun 2001, merupakan upaya untuk mendekatkan kekuasaan kepada masyarakat. Idealnya, aspirasi suatu kelompok bisa langsung tertampung di daerah dan bisa langsung direspon secara cepat oleh pemerintah daerah. Harapannya, pemerintah daerah bisa melayani kehendak warganya dengan cepat.

Munculnya aspirasi formalisasi Syariat Islam di beberapa daerah tentu harus diberi ruang untuk bisa menyalurkan ekspresinya. Penulis sepakat bahwa hal ini harus diberi ruang sebagai bagian dari kebebasan berpendapat yang menjadi prinsip demokrasi. Namun demikian, ketika aspirasi ini hendak menjadi keputusan publik atau menjadi kebijakan publik, maka pemerintah harus membuka ruang bagi semua kelompok untuk menyampaikan pendapat.

Ruang ini harus disediakan dan difasilitasi oleh pemerintah sebagai arena dialog yang mempertemukan semua kelompok dan tidak bisa didominasi satu kelompok. Ini mengingat bahwa ketika aspirasi tersebut menjadi kebijakan publik, tentu ia akan mengatur semua warga yang ada di daerah bersangkutan. Kebijakan publik seharusnya tidak hanya mengatur suatu kelompok tertentu.

Dalam konteks pluralisme politik, aspirasi formalisasi Syariat Islam yang digemakan oleh suatu kelompok, idealnya harus didialogkan dalam sebuah ruang yang mempertemukan semua kelompok yang berkepentingan. Pemerintah dalam hal ini tidak boleh mendukung suatu kelompok dan harus bisa mengayomi semua kelompok untuk berpendapat tanpa ada rasa takut.

Di tanah air, munculnya aspirasi untuk menerapkan Syari'at Islam harus diposisikan sebagai wacana publik yang terbuka untuk dibicarakan dalam ruang publik. Baik kelompok yang pro maupun kontra terhadap isu ini tidak boleh mendesak pemerintah untuk menjadikannya sebagai kebijakan publik. Pemerintah harus bisa menempatkan dirinya sebagai fasilitator yang bisa menampung aspirasi dan kepentingan semua kelompok sehingga tidak ada dominasi satu kelompok atas kelompok lain.

\section{F. Penutup}

Wacana formalisasi Syari'at Islam di Indonesia merupakan isu yang tergolong sensitif dan krusial. Berbagai gerakan yang menuntut pemberlakukan Syari'at Islam 
dengan dukungan instrumen negara, sebagaimana terlihat di beberapa daerah, memperlihatkan bahwa pemerintah belum bisa memposisikan dirinya sebagai instrumen publik yang seharusnya melayani kepentingan semua warga.

Munculnya perda bernuansa Syari'at Islam maupun surat edaran bupati yang diinisiasi Bupati maupun parlemen daerah, menunjukkan betapa kuat dan tingginya dominasi suatu kelompok dalam proses kebijakan publik. Dari perspektif pluralisme politik, hal ini tentu tidak bisa dibenarkan. Ini mengingat kekuasaan harus terdistribusi ke semua kelompok dan tidak boleh dinikmati satu kelompok saja. Selain itu, kebijakan publik juga seharusnya memiliki kewenangan yang mencakup semua masyarakat dan tidak hanya mengatur kelompok tertentu.

Kajian ini hendak menjelaskan bahwa formulasi kebijakan publik dalam negeri yang plural seperti Indonesia tidak bisa didominasi atau hanya menampung aspirasi kelompok tertentu. Ia juga harus bisa menampung suara semua kelompok dalam proses pembuatannya dan tidak "menganakemaaskan" atau memberi hak istimewa bagi kelompok tertentu.

Terkait dengan kewenangan otonomi daerah dan desentralisasi yang dimiliki pemerintah daerah, hal ini selayaknya tidak dimaknai untuk membuat kebijakan publik yang mengakomodasi satu kelompok saja dan mengabaikan suara kelompok lain yang kebetulan tidak dominan. Otonomi daerah ini selayaknya memungkinkan penyelenggaraan pemerintah yang mampu merespon kepentingan dan aspirasi setiap kelompok dan mendialogkan aspirasi tadi dengan kelompok lain secara cepat. Hal ini bisa mendorong mekanisme pembuatan kebijakan publik yang akomodatif dan responsif terhadap kepentingan semua kelompok. ${ }^{52}$

Pelajaran berharga dari kajian ini adalah pemerintah sebagai pihak yang memegang otoritas tertinggi dalam proses pembuatan kebijakan publik haruslah bisa menempatkan dirinya di atas kepentingan semua kelompok. Bupati atau Ketua DPRD merupakan pihak yang harus bisa mengakomodasi semua kepentingan dan aspirasi setiap kelompok atau masyarakat.

Sebagai rekomendasi, ke depan, kebijakan publik harus membuka ruang untuk memperdebatkan setiap aspirasi dan ini harus difasilitasi oleh pemerintah. Aspirasi

52 Dalam hal ini, penulis perlu menjelaskan bahwa dalam UU 32/2004 tentang Pemerintahan Daerah, disebutkan adanya enam urusan yang menjadi wewenang pemerintah pusat, yaitu; poltik luar negeri, pertahanan, keamanan, yustisi, moneter dan fiscal dan agama. Ini berarti bahwa otoritas untuk mengatur persoalan agama menjadi wewenang pemerintah pusat, bukan pemerintah daerah. 
untuk memformalisasikan atau menerapkan Syariat Islam melalui instrumen negara, misalnya, harus menjadi perdebatan publik yang bisa mempertemukan semua kelompok.

Memanfaatkan perspektif pluralisme politik, proses pembuatan kebijakan publik yang difasilitasi pemerintah harus bisa mempertimbangkan aspek risiko yang mungkin timbul dari setiap kebijakan publik yang hendak dibuat. Aspek risiko ini bisa dilihat, salah satunya, dengan mempertimbangkan siapa yang akan diuntungkan dan siapa yang akan dirugikan dari kebijakan publik tersebut.

Dengan demikian, setiap aspirasi formalisasi atau penerapan Syariat Islam melalui instrumen negara, hendaknya melalui perdebatan publik dalam sebuah ruang publik yang difasilitasi pemerintah. Perdebatan tersebut juga harus melibatkan semua kelompok. Selain itu, pemerintah sebagai pemegang otoritas publik harus mampu mengkaji sisi resiko dari setiap kebijakan publik yang dibuat.]

\section{DAFTAR PUSTAKA}

Ad'han, Syamsurijal dan Zubair Umam. 2006 "Perdaisasi Syariat Islam di Bulukumba." Jurnal Tashwirul Afkar, Edisi No. 20.

Amal, Taufik Adnan dan Samsu Rijal Panggabean. 2004. Politik Syariat Islam; Dari Indonesia hingga Nigeria. Jakarta: Pustaka Alvabet.

E. Apter, David. 1985. Pengantar Analisa Politik (Introduction to Political Analysis), terj. Tim Penerjemah Yasogama Yogyakarta. Jakarta: PT. Rajawali.

Effendy, Bahtiar. 1998. Islam dan Negara; Transformasi pemikiran dan Praktik Politik Islam di Indonesia, Terj: Ihsan Ali Fauzi. Jakarta: Paramadina.

Cholil, Suhadi. 2007. "Perda Syariat di Negeri Pancasila," dalam www.parasindonesia.com. Diakses pada 9 Februari.

Halim, Wahyuddin. 2006. "Gerakan Formalisasi Syariat Islam melalui Instrumen Negara; Refleksi Kritis atas KPPSI,” dalam Kamaruddin Amin, dkk., Quo Vadis Islamic Studies in Indonesia? (Current Trends and Future Challanges). Makassar, PPs UIN Alauddin Makassar.

Mulia, Siti Musdah . 2006. "Peminggiran Perempuan dalam Perda Syariat." Jurnal Tashwirul Afkear Edisi No. 20. 
Reid, Anthony. 1988. Southeast Asia in The Age of Commerce 1450-1680. Vol. 1: The Lands Below the Winds. New Haven: Yale University Press.

Smith, Martin. 1995. "dalam David Marsh dan Gerry Stoker (eds), Theory and Methods in Political Science. Basingstoke: Macmillan.

SP, Anom. 2002. "Gempa Tektonik Syariat Islam di Daerah; Mengungkap Rencana Strategis 2001-2005 di Tasikmalaya.” Jurnal Tashwirul Afkar, Edisi No. 12.

Yunanto, S. et al. 2003. Gerakan Militan Islam di Indonesia dan di Asia Tenggara. Jakarta: The Ridep Institute.

Zada, Khamami. 2002. "Wacana Syariat Islam; Menangkap Potret Gerakan Islam di Indonesia." Jurnal Taswirul Afkear Edisi No. 12.

Zein, Kurniawan dan Saifuddin HA (ed). 2001. Syariat Islam Yes, Syariat Islam No; Dilema Piagam Jakarta dalam Amandemen UUD 1945. Jakarta: Paramadina.

\section{Koran dan Majalah}

"Pdt Gara: Hormati Kebebasan Berpendapat," Manado Post, 29 Agustus 2001.

"Minahasa Kecam Pemberlakuan Syariat Islam di Jawa," Manado Post, 29 Agustus 2001.

"Rame-rame Formalisasi Syariat Islam,” Halqoh, Edisi XVI/2002.

“Gairah Syariat Islam di Berbagai Daerah,” Suara Hidayatullah, Juli 2000.

Tempo, 14 Mei 2006.

“91,11 persen Setuju Syariat Islam -Hasil Jajak Pendapat Pemprov Sulsel,” Fajar, 27 Januari 2003.

Nurlis E. Meuko dan Irmawati, "Pecut Bambu Dari Bulukumba," dalam Tempo, 14 Mei 2006.

Wahid, Marzuki., "Syariat Islam Butuh Reinterpretasi," dalam Halqoh, Edisi XVI/ 2002. 